\title{
Active Power Decoupling for Current Source Converters: An Overview Scenario
}

\author{
Jianhua Zhang ${ }^{1}$, Hao Ding ${ }^{1} \mathbb{D}$, Baocheng Wang ${ }^{1}$, Xiaoqiang Guo ${ }^{1, *}$ and \\ Sanjeevikumar Padmanaban 2 (D) \\ 1 Department of Electrical Engineering, Yanshan University, Qinhuangdao 066004, China; \\ zjh_163com@163.com (J.Z.); dinghao@ysu.edu.cn (H.D.); bcwang@ysu.edu.cn (B.W.) \\ 2 Department of Energy Technology, Aalborg University, 6700 Esbjerg, Denmark; san@et.aau.dk \\ * Correspondence: gxq@ysu.edu.cn
}

Received: 29 December 2018; Accepted: 2 February 2019; Published: 8 February 2019

\begin{abstract}
For single-phase current source converters, there is an inherent limitation in DC-side low-frequency power oscillation, which is twice the grid fundamental frequency. In practice, it transfers to the DC side and results in the low-frequency DC-link ripple. One possible solution is to install excessively large DC-link inductance for attenuating the ripple. However, it is of bulky size and not cost-effective. Another method is to use the passive LC branch for bypassing the power decoupling, but this is still not cost-effective due to the low-frequency LC circuit. Recently, active power decoupling techniques for the current source converters have been sparsely reported in literature. However, there has been no attempt to classify and understand them in a systematic way so far. In order to fill this gap, an overview of the active power decoupling for single-phase current source converters is presented in this paper. Systematic classification and comparison are provided for researchers and engineers to select the appropriate solutions for their specific applications.
\end{abstract}

Keywords: current source converter; power decoupling; power ripple

\section{Introduction}

The current source converters have unique features, such as inherent short-circuit capability, no electrolytic capacitor, step-up voltage capability and high reliability, and they have been widely used in applications such as smart microgrids [1], industrial uninterrupted power supplies (UPS) [2], Superconductor Magnetic Energy Storage (SMES) [3], photovoltaic power systems [4], high voltage direct current (HVDC) transmission systems and flexible AC transmission (FACT) systems [5]. There are many key technique issues that need to be solved for the converter, such as the leakage current problem, the efficiency problem, and so on [6-11]. For the single-phase current source converter, there is an inherent limitation of AC-side low-frequency power oscillation, which is twice the grid fundamental frequency. It transfers to the DC side and results in the low-frequency DC-link ripple. It has many unfavorable disadvantages. For example, it may reduce the efficiency of the maximum power point (MPPT) tracking in photovoltaic applications. Therefore, it could lead the light emitting diode (LED) lamps to flicker [12]. In addition, it may cause the battery to overheat and reduce the life of fuel cells $[13,14]$. This is the reason why the power decoupling techniques are popular in both academic and industrial fields.

Basically, the above-mentioned power ripple can be attenuated by increasing the DC-link inductance. However, it is of bulky size and not cost-effective. Another method is to use the passive LC branch for bypassing the power ripple, but it is still not cost-effective due to the low-frequency LC circuit. Recently, active power decoupling techniques have been reported to deal with this problem. Many interesting topologies have been reported in the last decades [15-24]. For example, a buck 
type circuit, boost type circuit or buck-boost type circuit is applied as the auxiliary power decoupling circuit [25]. Another method reported in [26,27] uses two additional capacitors placed on the AC side to achieve power decoupling without any auxiliary switches. The decoupling topology using the center tap of the isolation transformer has been proposed [28-30]. The above-mentioned topologies are the voltage-source converters. On the other hand, the active power decoupling techniques for the current source converters have been sparsely discussed in the literature. For example, Sun et al. proposed an interesting circuit, which used a decoupling circuit connect in series with the main converter [31]. This power decoupling method has the advantage of control flexible. For the current source $\mathrm{AC} / \mathrm{DC} / \mathrm{AC}$ converter, the low-frequency ripple also exists on the DC-side. There is a kind of power decoupling circuit proposed in [32]. The capacitor is used as a power compensation component, while the $\mathrm{H}$ bridge circuit is applied for power decoupling. Another circuit in [33] uses the buffer capacitor to achieve the power decoupling on the DC-side. A circuit structure connected in parallel with the current source converter on the DC-side is proposed in [34]. For this circuit structure, the buffer capacitor also connects in series with the current source converter when the circuit works in power decoupling mode. Aside from that, the power decoupling circuit can be installed on the AC side [35], which needs an extra bridge arm. A similar circuit structure is proposed in [36-38]. A modified differential connected circuit structure is proposed in [39]. To decrease the number of auxiliary switches, a kind of power decoupling circuit with the lower switches multiplexing has been proposed [40]. The modified power decoupling circuits, which need no extra switch, are proposed in $[41,42]$. A decoupling topology using the isolation transformer for the current source converter is derived from [43]. The power decoupling circuit is independent with the main converter. However, it needs a transformer to isolate the decoupling circuit and the main current source converter.

In summary, the power decoupling method can be divided into the capacitive and inductive compensations [44]. For the active power decoupling for the current source converters, the capacitor is generally applied as the ripple power compensation device. According to the relation between the auxiliary power decoupling circuit and the main circuit, the ripple power decoupling circuit can be divided into independent and non-independent structures [45]. The following will present the details, and the rest of the paper is organized as follows. The theoretical analysis of power oscillation and ripple for the single-phase current source converter is presented in Section 2. The versatile power decoupling circuits are illustrated and discussed in Sections 3 and 4. Aside from that, a comparison of different power decoupling circuits is provided in Section 5 .

\section{Problem Definition}

The basic single-phase current source converter is illustrated in Figure 1.

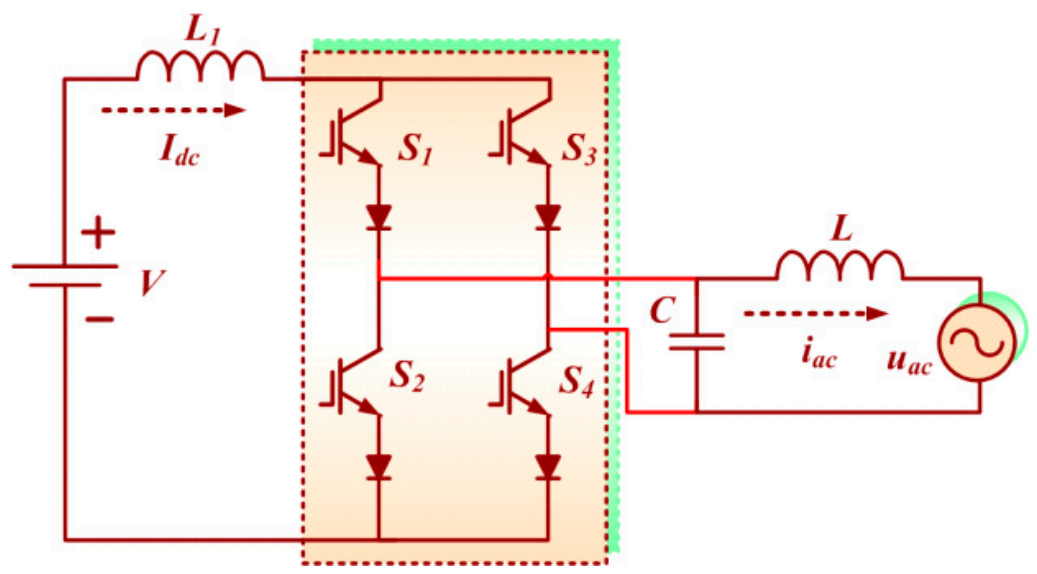

Figure 1. Basic single-phase current source converter. 
In Figure 1, the grid voltage $u_{a c}$ and grid current $i_{a c}$ can be represented as:

$$
\begin{gathered}
u_{a c}=V \cdot \cos (\omega \cdot t), \\
i_{a c}=I \cdot \cos (\omega \cdot t+\varphi),
\end{gathered}
$$

In Equation (2), $\varphi$ represents the phase-angle between grid voltage and current. The output power $P_{a c}$ can be represented as

$$
P_{a c}=u_{a c} \cdot i_{a c}=\frac{V I \cos (\varphi)}{2}+\frac{V I \cos (2 \omega \cdot t+\varphi)}{2},
$$

From (3), it can be observed that $P_{a c}$ has the ripple power at twice line frequency.

The constant power $P_{o}$ can be represented as:

$$
P_{o}=\frac{V I \cos (\varphi)}{2},
$$

Therefore, the ripple power $P_{r}$ can be represented as:

$$
P_{r}=\frac{V I \cos (2 \omega \cdot t+\varphi)}{2}
$$

According to the power conservation law, the ripple power also exists on the DC side.

Figure 2 reflects the relation between the output power and ripple power. The AC power $P_{a c}$ consists of the constant power $P_{o}$ and ripple power $P_{r}$. According to the power conservation law, the auxiliary circuit is needed to attenuate the ripple. When the AC power $P_{a c}$ is larger than power $P_{o}$, the ripple power is absorbed by the compensating circuit. The auxiliary circuit will emit the energy to compensate the AC power $P_{a c}$ when the AC power $P_{a c}$ is less than $P_{o}$. It is the basic mechanism for the power decoupling method.

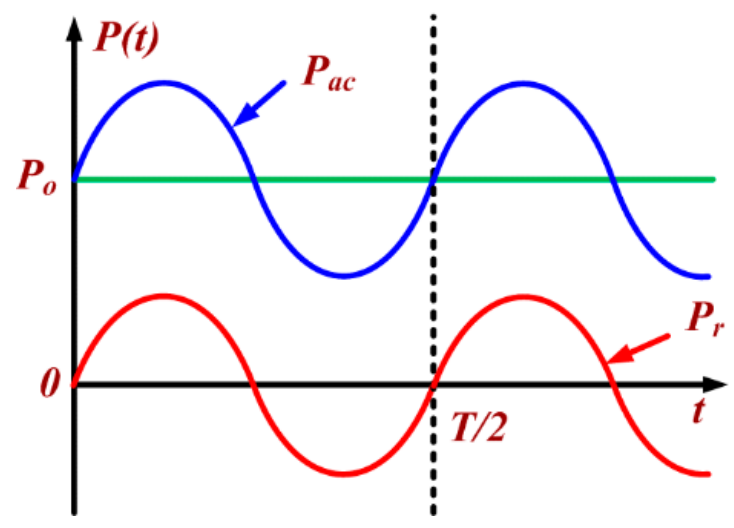

Figure 2. Output power and ripple power.

\section{DC-Side Power Decoupling Solutions}

The structure shown in Figure 3a connects in series with the main converter on the DC side to compensate for the ripple power. The capacitor is used as a passive component to bypass the ripple power. The circuit shown in Figure $3 \mathrm{~b}$ is a simplified circuit in which the number of the auxiliary switch is reduced. However, the complexity of the circuit control will increase. 


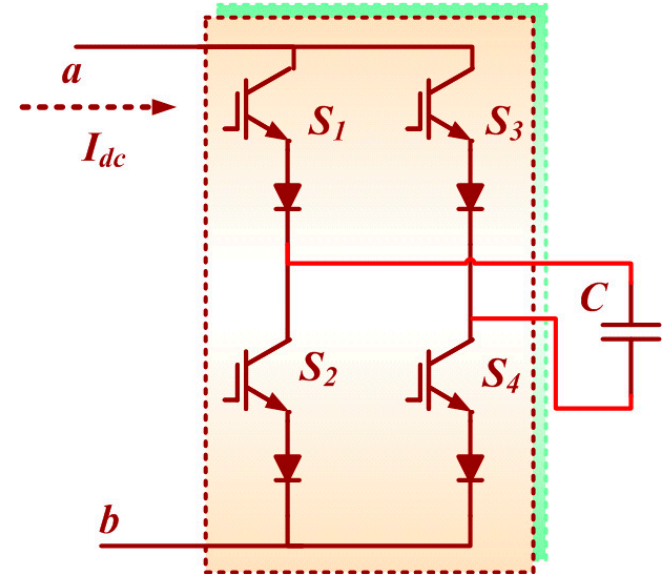

(a)

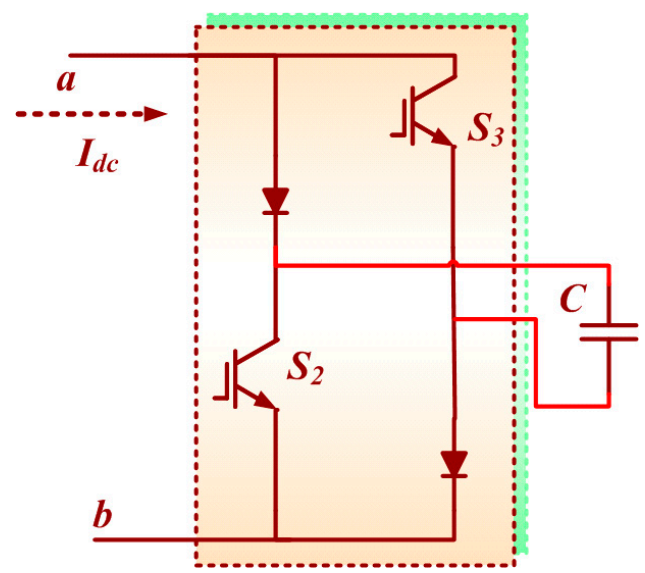

(b)

Figure 3. (a) H-bridge decoupling circuit; (b) Simplified H-bridge decoupling circuit.

The converter applies the $\mathrm{H}$ bridge structure shown in Figure 4. The voltage of the buffer capacitor is lower than the DC-side voltage. For this circuit, the circuit modes and power decoupling process is introduced as follows. When the auxiliary switches $S_{5}$ and $S_{6}$ are turned on, the buffer capacitor is charged. When switches $S_{5}$ and $S_{6}$ are turned off, the buffer capacitor discharges through the auxiliary diode $D_{1}$ and $D_{2}$. When only the switch $S_{5}$ or $S_{6}$ is turned on, the buffer capacitor is bypassed. The voltage of the buffer capacitor controlled to compensate the ripple power according the real time ripple power on the system. The auxiliary decoupling circuit is controlled independently with the main converter. For the function of the power decoupling circuit, the ripple power is eliminated on the DC side, and the DC-side inductance can be relatively small.

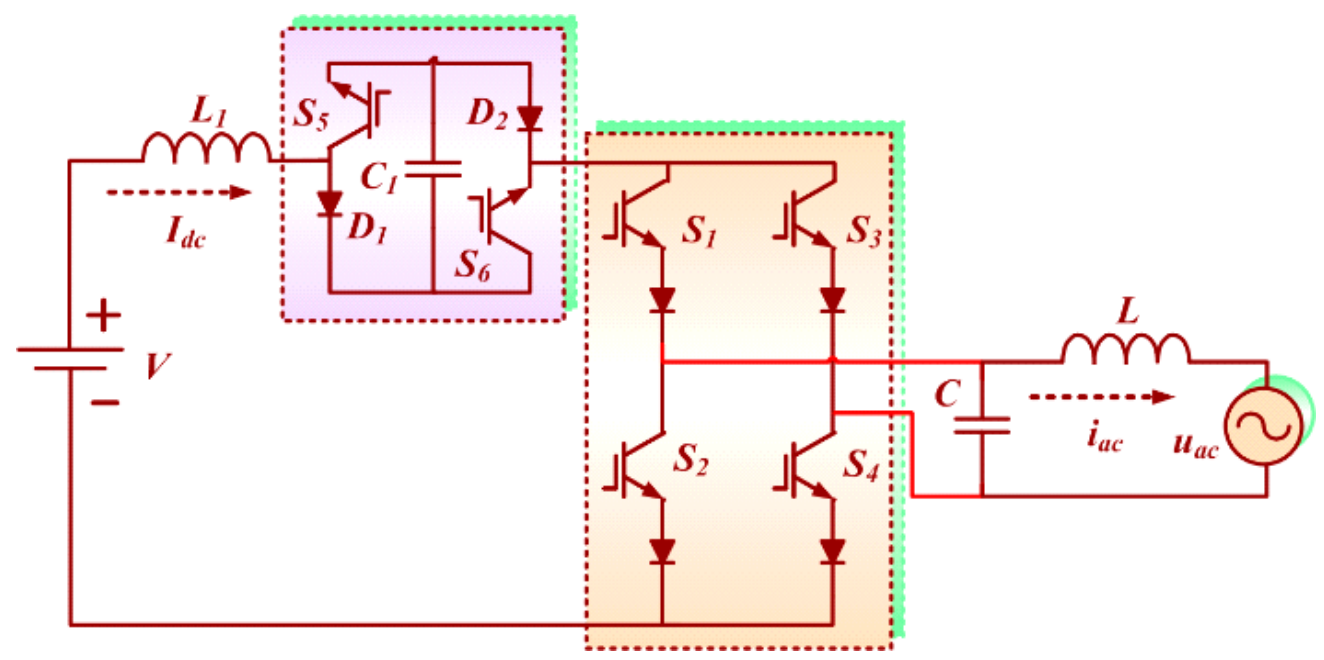

Figure 4. Power decoupling solution in [31].

Another power decoupling circuit applying the series power decoupling circuit is proposed as shown in Figure 5. The AC/DC/AC converter has three bridge arms, which play the role of rectification and inversion with sharing a bridge arm. The bridge arm ' $a$ ' and bridge arm ' $c$ ' work as rectification. And the bridge arm ' $b$ ' and bridge arm ' $c$ ' work as inversion. The decoupling circuit is in series with the DC-link in which capacitor applied to compensate the ripple power. 


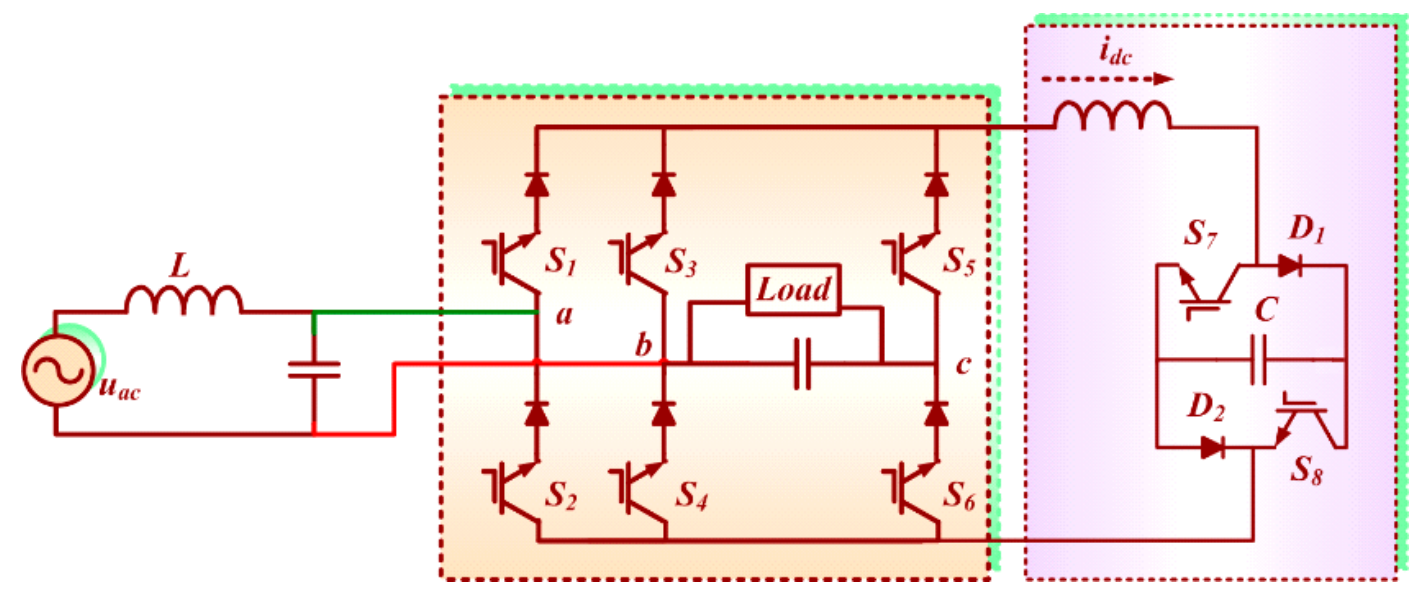

Figure 5. Power decoupling solution in [32].

Compared with a conventional AC/DC/AC converter, the circuit needs fewer switches. However, the system may be broken down when the auxiliary decoupling circuit is out of order, since the decoupling circuit is connected in series with the main circuit on the DC-side.

This type of power decoupling structure shown in Figure 3 has the advantages of a simple circuit structure, being independent with a main converter and flexible control. There are several other types of circuit structures, introduced as follow.

As shown in Figure 6, the auxiliary decoupling circuit is connected in parallel with the main converter. The buffer capacitor $C$ is used to compensate the ripple power. Taking the positive period for example, the operation modes and power decoupling process are discussed as follows.

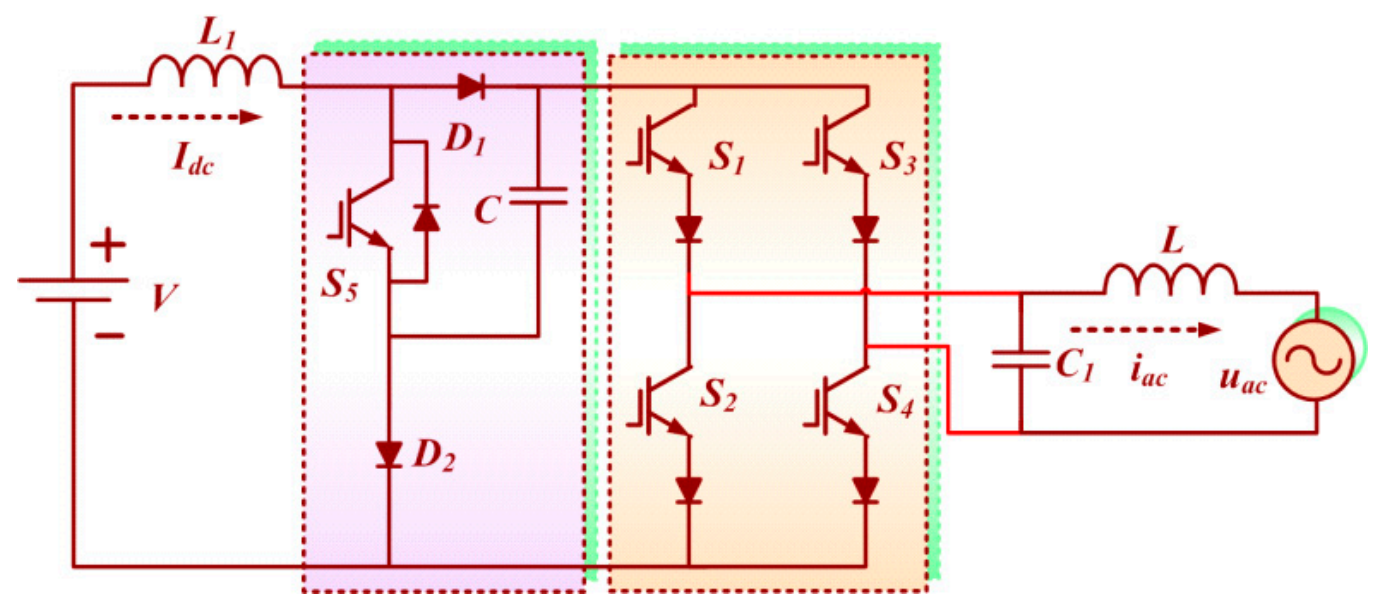

Figure 6. Power decoupling solution in [33].

In the positive period, the switches $S_{3}$ and $S_{2}$ are turned off, the switches $S_{1}, S_{4}$ and extra switch $S_{5}$ work to implement the energy transfer and power decoupling. When $S_{5}$ is turned on and the capacitor voltage $u_{\mathrm{c}}$ of $C$ is lower than the grid voltage, the diode $\mathrm{D}_{2}$ will be turned on. The DC current will flow through the circuit consisting of switch $S_{5}$ and diode $D_{2}$. When $S_{5}$ is turned on and the capacitor voltage of $C$ is higher than the grid voltage, the diode $D_{2}$ will turn off and the capacitor $C$ will discharge connected in series with the main converter. When $S_{5}$ is turned off and the main converter switches $S_{1}$, $S_{4}$ are turned off, the capacitor $C$ is charged through the diodes $D_{1}$ and $D_{2}$. When $S_{5}$ is turned off and the main converter switches $S_{1}$ and $S_{4}$ are turned on, the capacitor $C$ is bypassed. Meanwhile, the grid current and the voltage of the power compensated capacitor are controlled. In contrast to the circuit structure shown in Figure 4, the auxiliary decoupling circuit is depended on the main converter. When the grid voltage is negative, the circuit state is similar with the positive period. 
As shown in Figure 7, the auxiliary decoupling circuit consists of one bridge arm and a bidirectional buck-boost circuit, which work to compensate the ripple power. The voltage of capacitor $C_{f}$, is controlled to keep constant. The capacitor $C$ is used to compensate the ripple power.

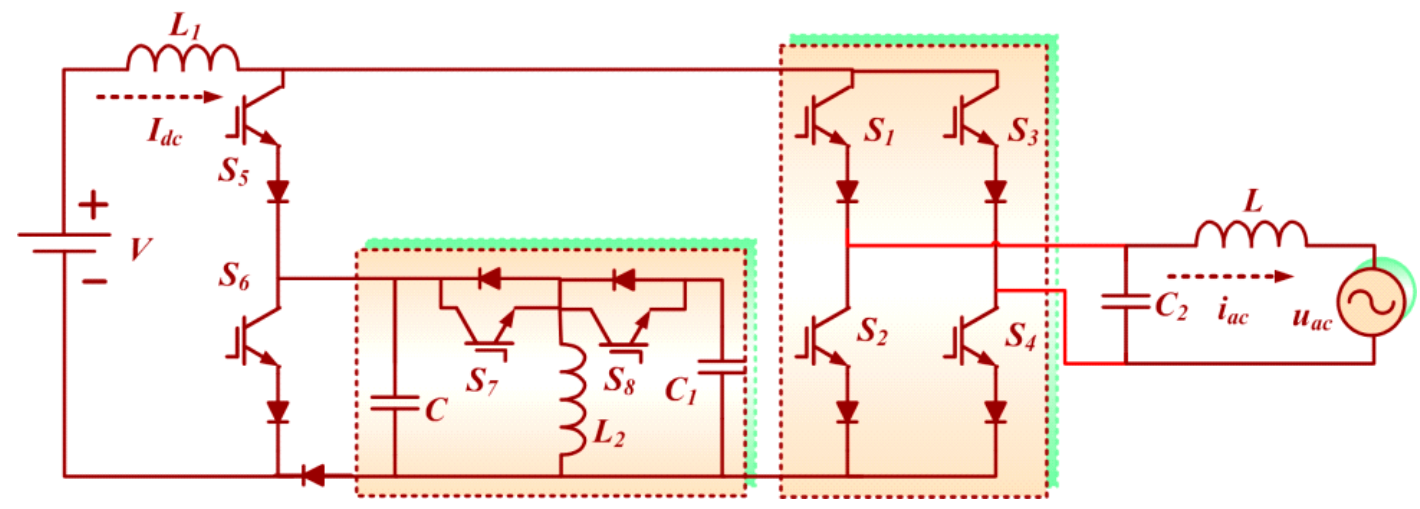

Figure 7. Power decoupling solution in [34].

For this circuit, the operation modes and power decoupling process are discussed as follows. When all the main converter switches $S_{1}-S_{4}$ are turned off, the extra switch $S_{5}$ remains on. In this state, the DC current is bypassed by the auxiliary bridge while the switch $S_{6}$ is on. The buffer circuit supplies zero voltage to the DC side. While switch $S_{6}$ is turned off, the buffer circuit connects in series with the DC side to compensate the ripple power. When the main converter switches $S_{1}$ and $S_{4}$ (or $S_{2}$ and $S_{3}$ ) are turned on, the switch $S_{5}$ keep off. In this state, when switch $S_{6}$ is turned off, the buffer circuit is isolated with the source. When switch $\mathrm{S}_{6}$ is turned on, the buffer circuit connects in series with DC side. The switch states of $S_{5}$ and $S_{6}$ are dependent with the main circuit.

The decoupling circuit shown in Figures 6 and 7 connects in parallel with the main converter but the buffer capacitor is connected in series with the main converter.

\section{The Typical Circuit Structure of AC Side Decoupling}

An interesting circuit structure to decouple the ripple power on the AC side is proposed in [35].

As shown in Figure 8, there is an auxiliary bridge arm of the converter. The capacitor $C_{1}, C_{2}$ and $C_{3}$ work as power compensation capacitor connected in star structure. The capacitor $C_{2}$ and $C_{3}$ also work as AC filter capacitor. To compensate the ripple power, the decoupling circuit shares two arm bridges with the main converter to control the capacitor voltage effectively. The circuit shown in Figure 9 is one of the simplified circuits.

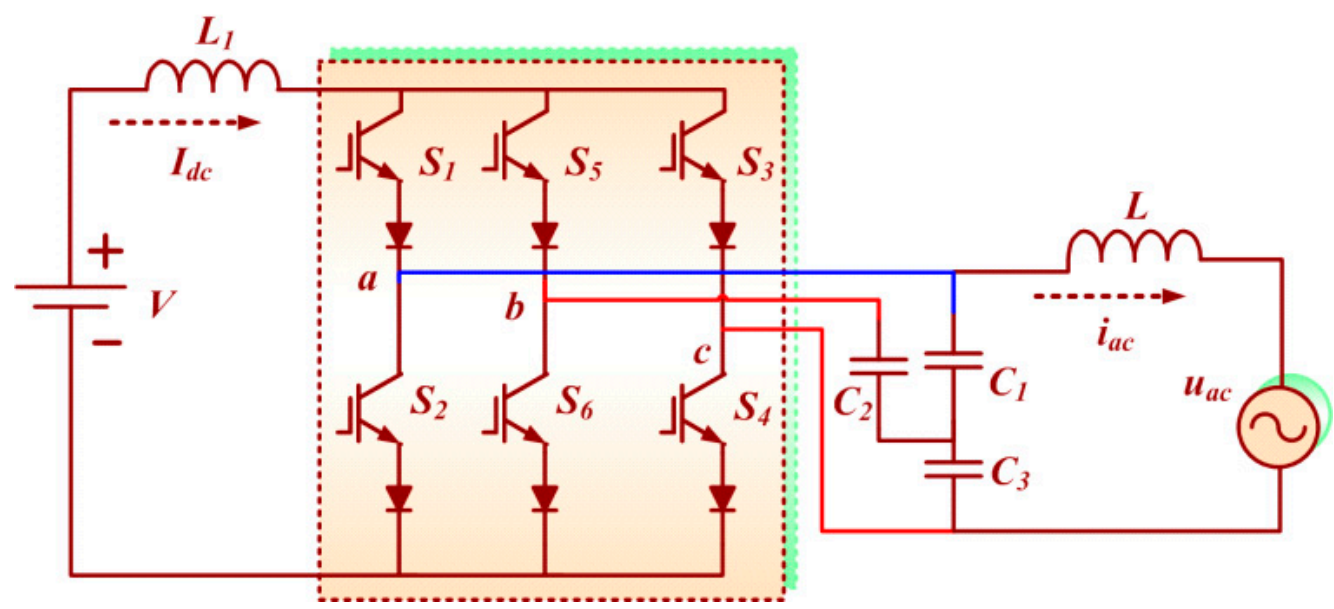

Figure 8. Power decoupling solution in [35]. 


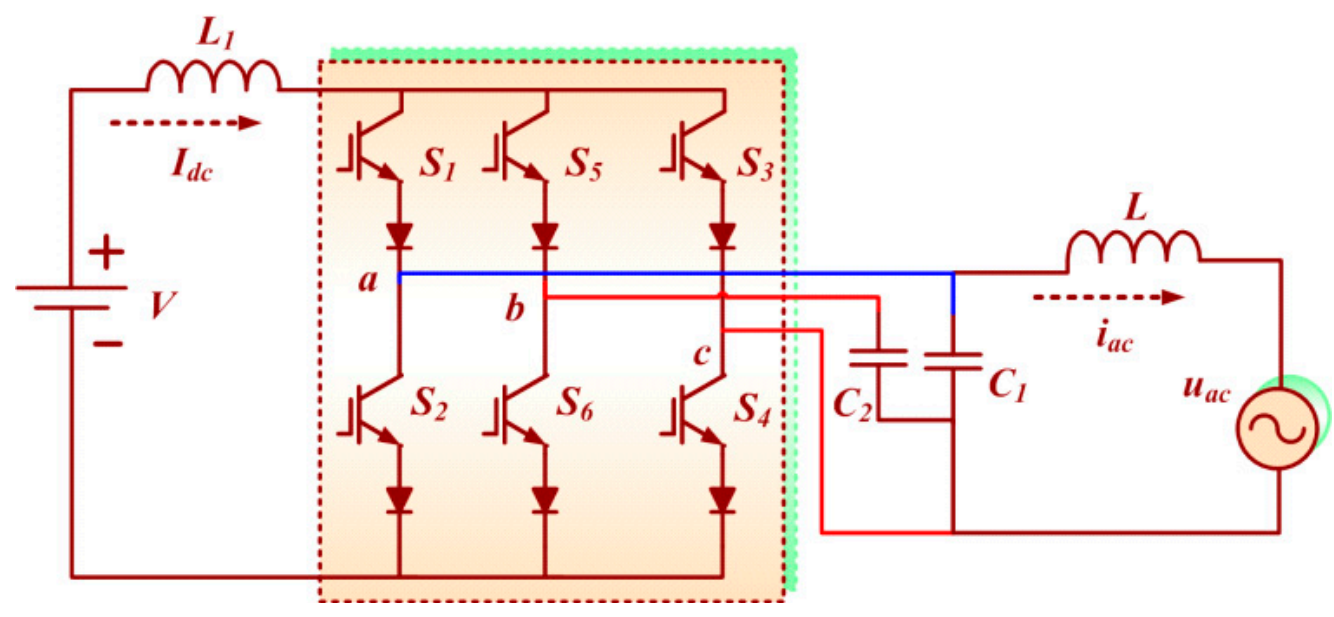

Figure 9. Power decoupling solution in [35].

The decoupling capacitor $C_{3}$ of Figure 8 can be seen as a wire in the circuit of Figure 9. The decoupling capacitor $C_{1}$ works as the AC filter capacitor.

The literature [36] introduces a circuit which also compensates the ripple power on the AC-side. It is a duality with the voltage source converter introduced in [37]. It is similar to Figure 9 in circuit structure.

As shown in Figure 10, the circuit topology consists of three bridge arms. The bridge arm ' $b$ ' is connected with bridge arm ' $c$ ' through buffer capacitor $C$. By controlling the current flowing through capacitor $C$, the ripple power can be compensated. Different from the circuit shown in Figure 9, the circuit only has one decoupling capacitor. Hence, it is easy to control.

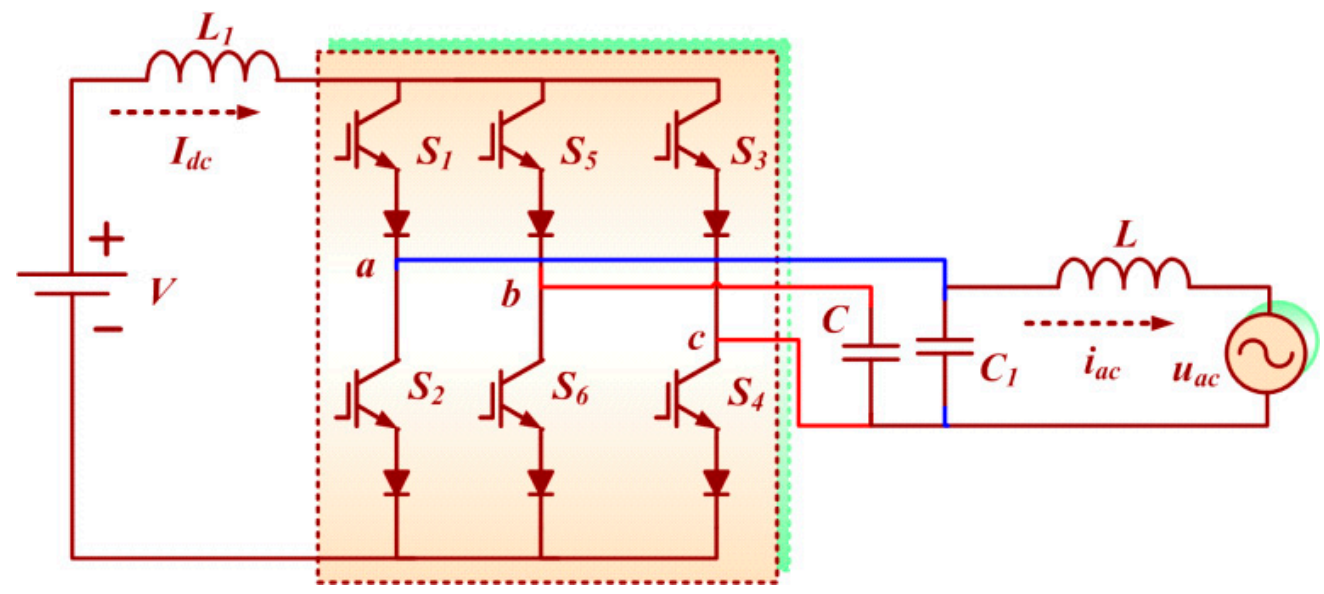

Figure 10. Power decoupling solution in [36].

For the single-phase current source $\mathrm{AC} / \mathrm{DC} / \mathrm{AC}$ converter, the ripple power exists at the source and load sides. To eliminate the low frequency DC-link energy, an interesting circuit is proposed in [38], as shown in Figure 11. The auxiliary power decoupling circuits were applied on the AC side to compensate for the ripple power, which is similar to the decoupling method shown in Figure 10. Compared with the power decoupling method shown in Figure 11, this circuit needs more extra switches. Henceforth, it has more switch losses.

A kind of differently-connected circuit was applied to achieve the ripple power decoupling as shown in Figure 12a.

As shown in Figure 12a, the current source inverter is composed of two H-type inverter which is connected in a differential way. The power decoupling circuit applies two capacitors as the power compensation device, which is placed at AC side. The number of switches is high as shown in 
Figure 12a. A modified circuit structure is proposed in [39]. The middle two bridge arms of Figure 12a were synthesized into one bridge arm, as shown in Figure 12b. The power compensation capacitors $C_{1}$ and $C_{2}$ shown in Figure $12 \mathrm{~b}$ were used also as the AC filter capacitors. The phase of the ripple voltage part of the two capacitors was reversed. So, the total voltage of the two capacitors synchronizes with the grid voltage.

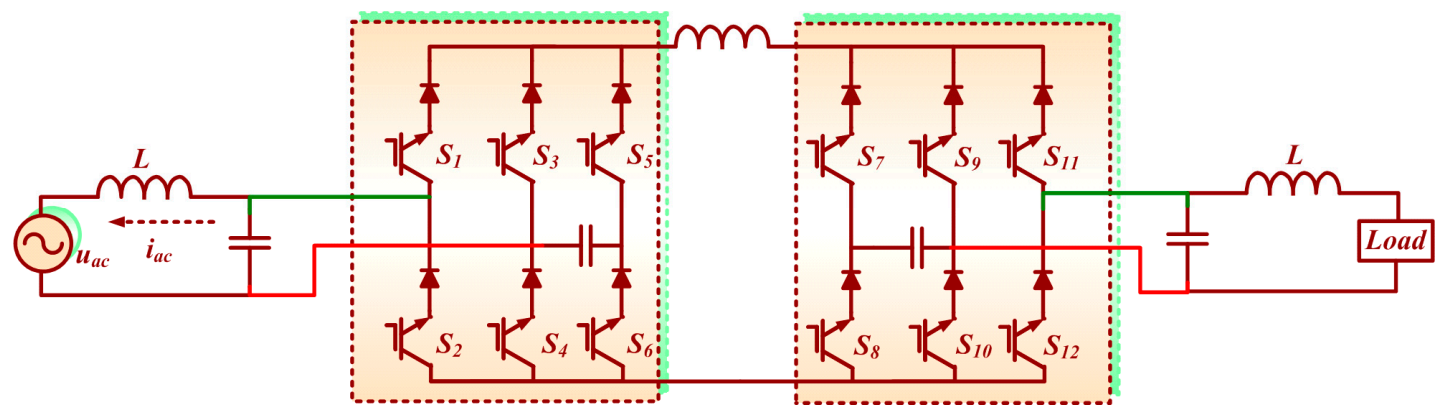

Figure 11. Current source converter with two auxiliary decoupling circuits [38].

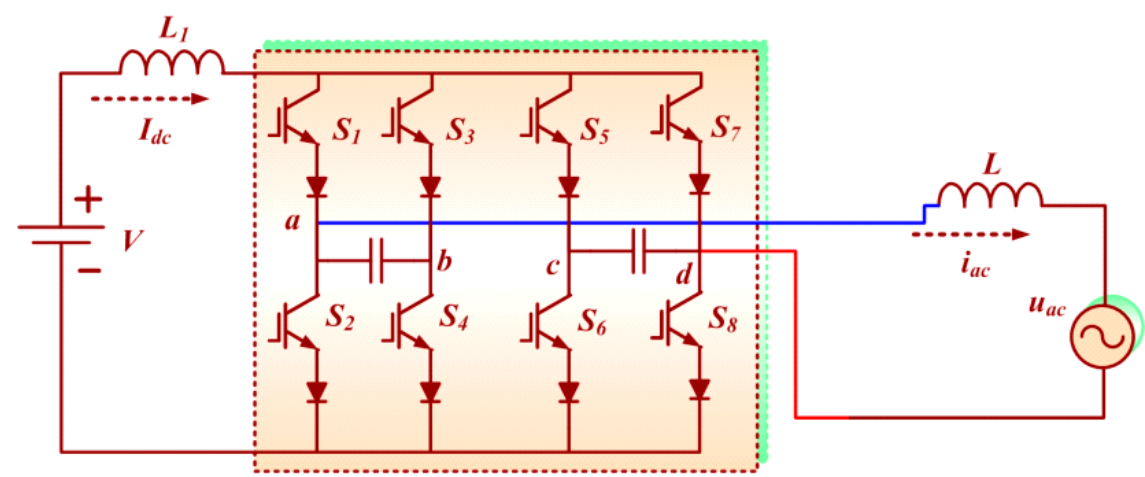

(a)

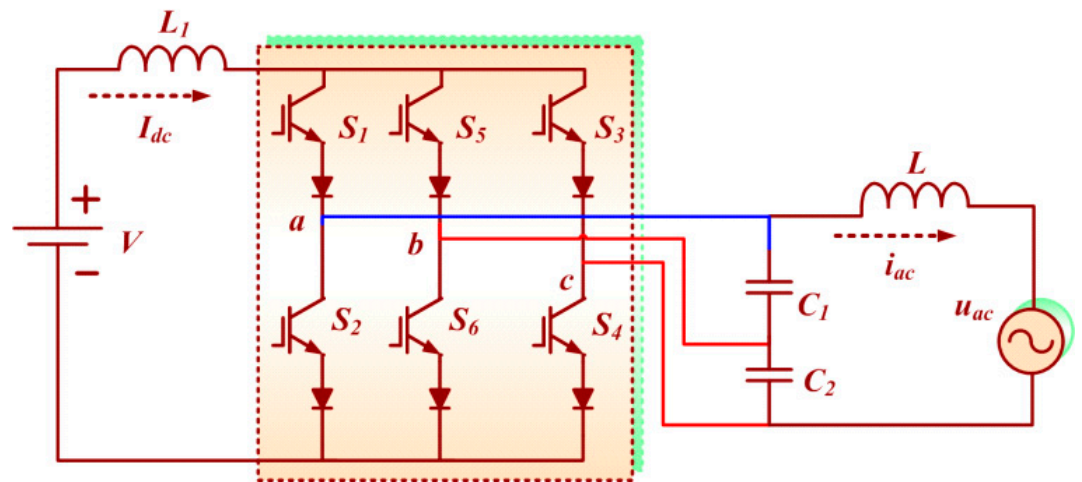

(b)

Figure 12. Topology of current source converter with differential-connected structure [39]. (a) four leg configuration; (b) three leg configuration.

As stated above, the auxiliary power decoupling circuit shares the bridge arm with the main converter. The decoupling circuit, which shares the lower switches with the main inverter is proposed in [40]. As shown in Figure 13, the decoupling circuit part is marked by the lower dotted line. The main converter is marked by the upper dotted line. It is obvious that the multiplexed switches are the lower switches of the main converter. Compared to a conventional independent circuit, the dependent circuit needs fewer switches. To decrease the number of extra switches, the modified circuit of Figure 13 is proposed in [41,42]. 


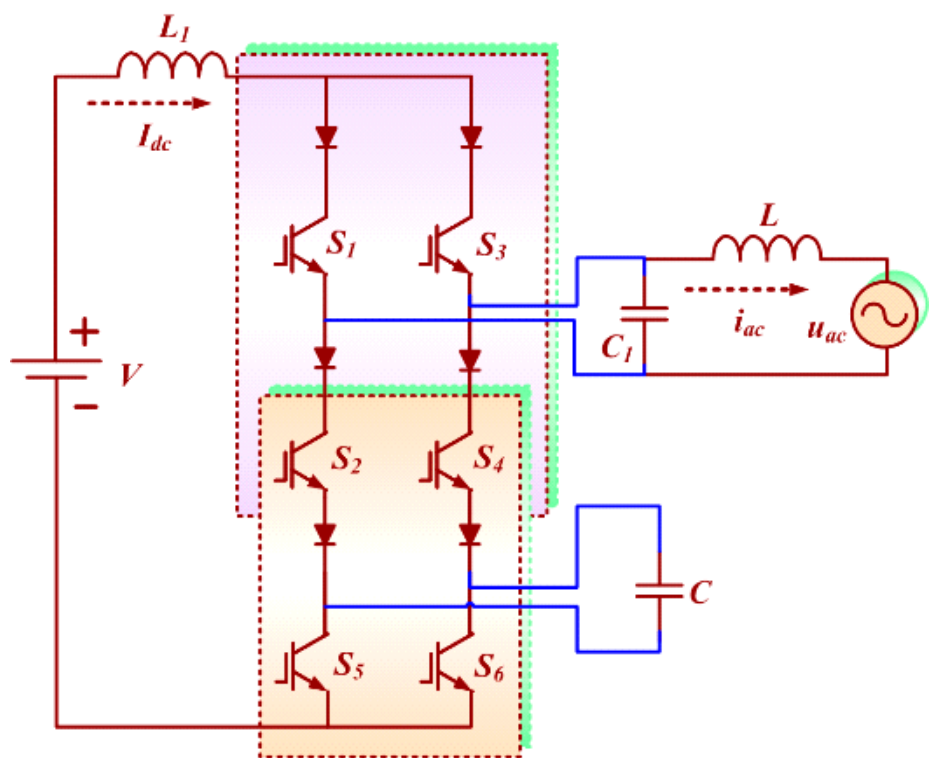

Figure 13. Power decoupling solution in [40].

As shown in Figure 14a, there is an auxiliary capacitor which connects between the bridge arms. There are two circuit states to charge the capacitor voltage. When the switches $S_{1}, S_{3}$ and $S_{4}$ are turned on, the capacitor $C$ is charged. While the switch $S_{2}$ is turned on, the capacitor $C$ discharged. The voltage of capacitor $C$ is controlled to compensate for the ripple power. This circuit only needs one auxiliary diode to limit the discharging loop of the buffer capacitor. Compared with Figure 14a, the circuit shown in Figure 14b has two auxiliary capacitors. Thus, the circuit has more optional circuit states.

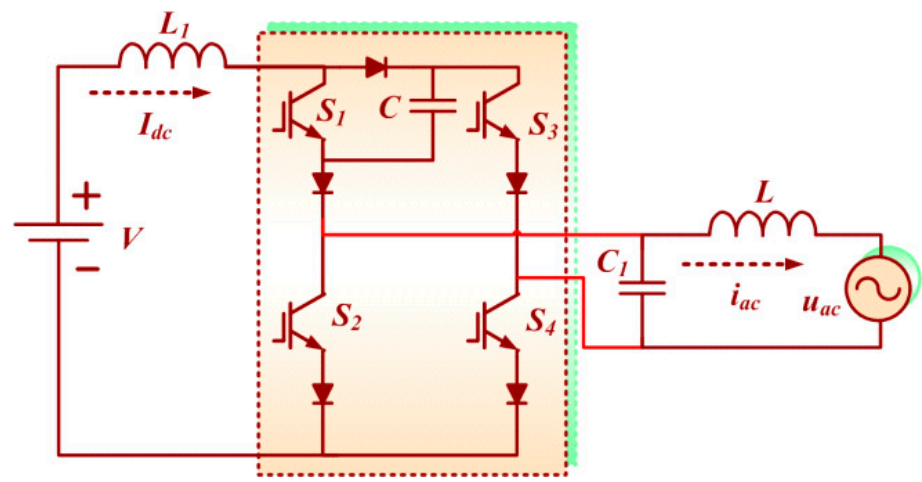

(a)

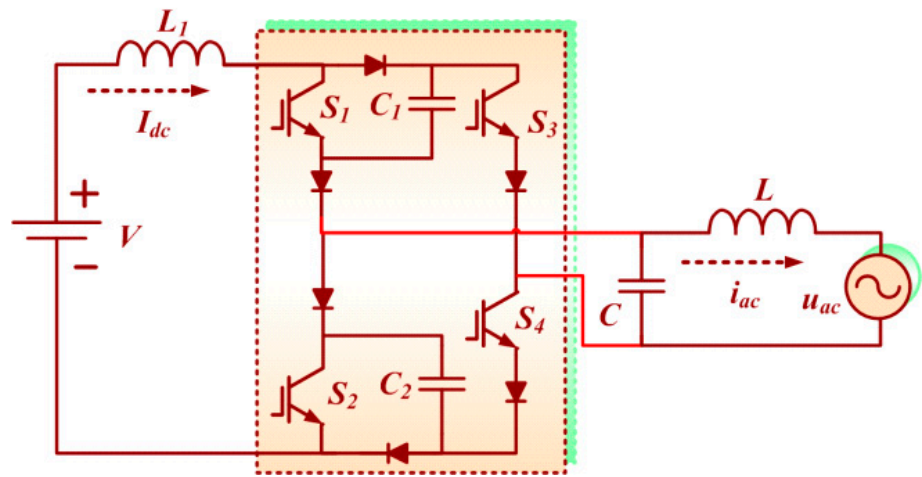

(b)

Figure 14. Power decoupling solution with no auxiliary switch [41,42]. (a) 1-capacitor configuration; (b) 2-capacitor configuration. 
A decoupling topology using the isolation transformer for current source converter is derived from [43]. In Figure 15, it can be observed that the auxiliary power decoupling circuit is separated from the output circuit. The auxiliary power decoupling circuit is independent from the main converter. Compared to the dependent power decoupling circuit, control of independent circuit is simple. However, it needs more auxiliary switches and an extra transformer.

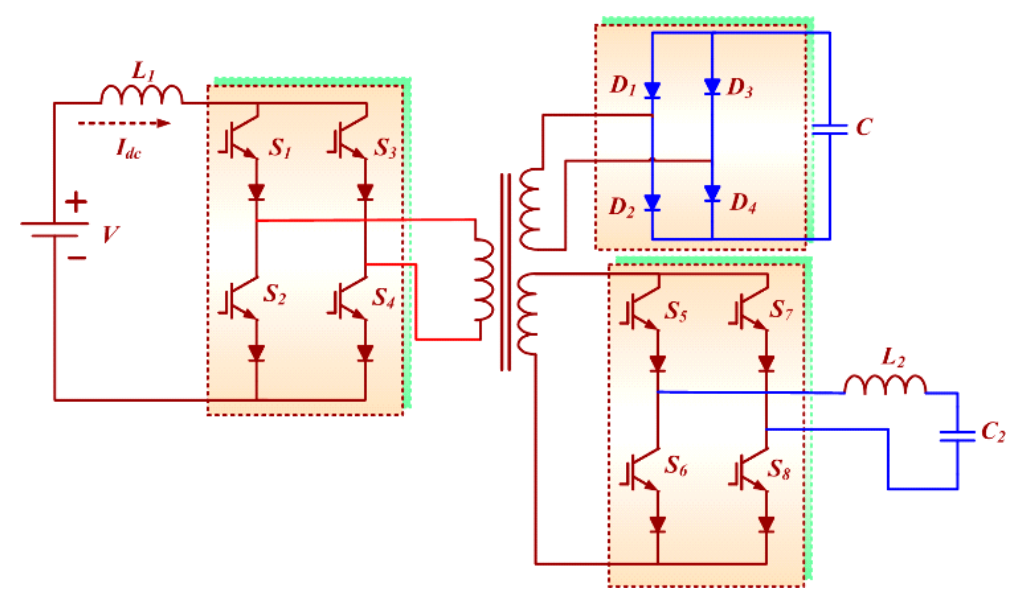

Figure 15. Power decoupling solution with three-port circuit [43].

\section{Discussions and Conclusions}

The ripple power in the single-phase current source converter has an adverse effect on the performance of the system. That is the reason why power decoupling is important for single-phase current source converters. This paper has presented a systematic review of the power decoupling methods for single-phase current source converters. Typically, the capacitor is used as a buffer device for power decoupling [46-49]. According the relationship between the decoupling circuit and the main converter, the topology is divided into the independent and the dependent circuits. The dependent circuit needs few auxiliary switches. However, it is complex to control. The decoupling circuit can be placed on the DC-side or AC-side of the main converter. One of the DC-side decoupling circuits is shown in Figure 4. The H-bridge decoupling circuit is connected in series with the main converter. For this circuit structure, the power decoupling circuit is controlled independently with the main converter. Other circuit structures for DC-side power decoupling are shown in Figures 6 and 7. The auxiliary power decoupling circuit is in parallel with the main converter. The AC-side decoupling circuit shares bridge arms with the main converter. The typical structure is described as follows.

The circuit structure in Figure 16a needs two or more buffer capacitors to decouple the ripple power. The typical circuit structures are shown in Figures 8,9 and 12. The circuit structures in Figures 9 and 12 can be considered as the simplified circuit of Figure 8. For the circuit structure shown in Figure 16b, the decoupling circuit shares a bridge arm with the main converter. The typical circuit is shown as Figure 10. Only one buffer capacitor is needed for power decoupling. It can be considered similar to the circuit structure in Figure 8.

Regarding the two circuit structures shown above, the decoupling circuit is dependent on the main converter. They will interfere with each other, which results in output current distortion and increases the control complexity.

A comparison of these topologies is shown in Table 1. The structures of power decoupling circuits have different characteristics. For example, compared to the dependent decoupling circuit, the independent decoupling circuit is not influenced by the main converter. However, the independent decoupling circuit needs more extra switches. Readers might wonder which could be the best choice among these versatile solutions. The answer to this question is difficult because each of them has its own disadvantages and advantages. In this paper, an overview and comparison has carried out, and it 
is expected to provide a useful guide for researchers and engineers to select the appropriate power decoupling solution for their specific applications.

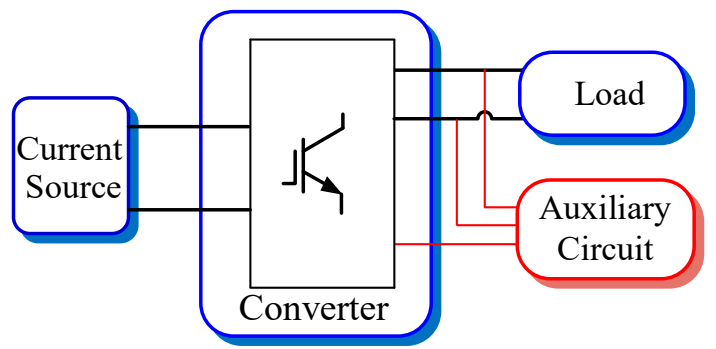

(a)

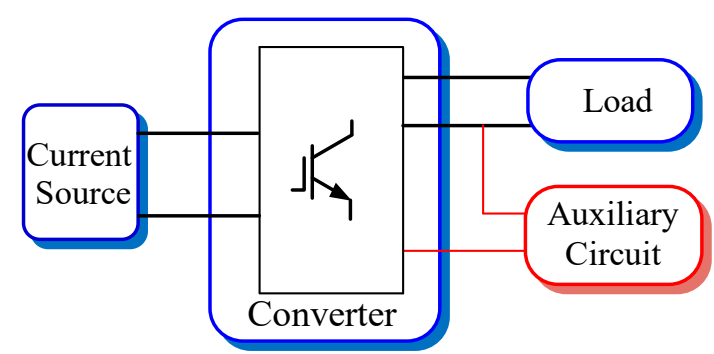

(b)

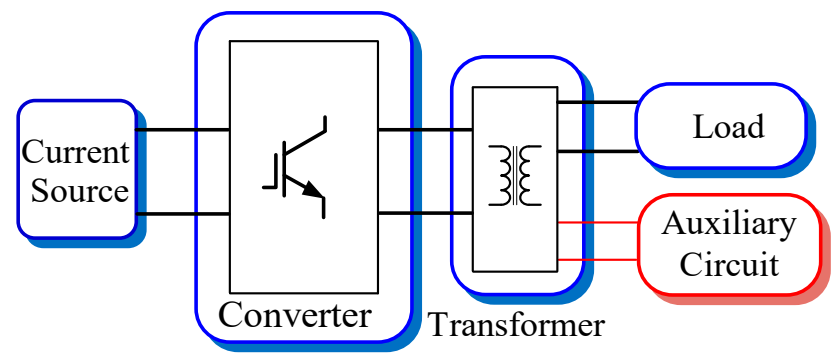

(c)

Figure 16. AC-side power decoupling circuit structure. (a) Share two bridge arms; (b) Share a bridge arm; (c) Three-port circuit.

Table 1. Comparison of versatile power decoupling circuits.

\begin{tabular}{|c|c|c|c|c|c|}
\hline & $\begin{array}{l}\text { Power } \\
\text { Rating }\end{array}$ & $\begin{array}{l}\text { Auxiliary } \\
\text { Components }\end{array}$ & $\begin{array}{l}\text { Connection } \\
\text { Method }\end{array}$ & Circuit Performance & Advantages and Disadvantages \\
\hline Figure 4 [31] & $139.2 \mathrm{~W}$ & $\begin{array}{l}1 \text { Capacitor } \\
(91.8 \mu \mathrm{F})+2 \\
\text { Switches }+2 \\
\text { Diodes }\end{array}$ & $\begin{array}{l}\text { In series } \\
\text { (DC side) }\end{array}$ & $\begin{array}{l}\text { Efficiency: } 84 \% \text {. } \\
\text { Effect: Second-order } \\
\text { harmonic current ripple is } \\
\text { reduced by } 87.99 \% \text {. } \\
\text { Dynamic response: } \\
\text { within } 5 \mathrm{~ms} \text {. }\end{array}$ & $\begin{array}{l}\text { Advantages: Easy control and } \\
\text { simple circuit structure. } \\
\text { Disadvantages: Endangering the } \\
\text { system stability due to the } \\
\text { connected power decoupling } \\
\text { circuit. }\end{array}$ \\
\hline Figure 6 [33] & $500 \mathrm{~W}$ & $\begin{array}{l}\text { 1 Capacitor } \\
(50 \mu \mathrm{F})+1 \\
\text { Switch }+2 \\
\text { Diodes }\end{array}$ & $\begin{array}{l}\text { In parallel } \\
\text { (DC side) }\end{array}$ & $\begin{array}{l}\text { THD: Less than } 5 \% \text {. The } \\
\text { output power factor can } \\
\text { reach to } 99.9 \% \\
\text { Efficiency: Maximum } \\
\text { efficiency of } 94.9 \% \\
\text { Effect: Voltage ripple is } \\
\text { reduced to } 8.87 \%\end{array}$ & $\begin{array}{l}\text { Advantages: System stability. } \\
\text { Disadvantage: Control is complex. }\end{array}$ \\
\hline Figure 7 [34] & / & $\begin{array}{l}1 \text { Capacitor }+4 \\
\text { Switches }+1 \\
\text { Diodes }\end{array}$ & $\begin{array}{l}\text { In parallel } \\
\text { (DC side) }\end{array}$ & $\begin{array}{l}\text { Effect: MPPT performance } \\
\text { can be improved for the } \\
\text { PV converter. }\end{array}$ & $\begin{array}{l}\text { Advantages: System stability. } \\
\text { Disadvantage: Circuit structure } \\
\text { complex, Much auxiliary switch. }\end{array}$ \\
\hline Figure 8 [35] & \multirow[t]{2}{*}{ / } & $\begin{array}{l}3 \text { Capacitors + } \\
2 \text { Switches }\end{array}$ & $\begin{array}{l}\text { In parallel } \\
\text { (AC side) }\end{array}$ & \multirow[t]{2}{*}{ / } & \multirow{2}{*}{$\begin{array}{l}\text { Advantage: Bridge arms } \\
\text { multiplexing, Less auxiliary } \\
\text { switches } \\
\text { Disadvantage: Control is complex. }\end{array}$} \\
\hline Figure 9 [35] & & $\begin{array}{c}2 \text { Capacitors + } \\
2 \text { Switches }\end{array}$ & $\begin{array}{l}\text { In parallel } \\
\text { (AC side) }\end{array}$ & & \\
\hline
\end{tabular}


Table 1. Cont.

\begin{tabular}{|c|c|c|c|c|c|}
\hline & $\begin{array}{l}\text { Power } \\
\text { Rating }\end{array}$ & $\begin{array}{c}\text { Auxiliary } \\
\text { Components }\end{array}$ & $\begin{array}{l}\text { Connection } \\
\text { Method }\end{array}$ & Circuit Performance & Advantages and Disadvantages \\
\hline Figure 10 [36] & $1 \mathrm{~kW}$ & $\begin{array}{l}1 \text { Capacitor } \\
(10 \mu \mathrm{F})+2 \\
\text { Switches }\end{array}$ & $\begin{array}{l}\text { In parallel } \\
\text { (AC side) }\end{array}$ & $\begin{array}{l}\text { Effect: The input current } \\
\text { ripple is reduced to } 1.86 \% \\
\text { of DC-link current. }\end{array}$ & $\begin{array}{l}\text { Advantages: Bridge arms } \\
\text { multiplexing, Control is easy } \\
\text { relatively. } \\
\text { Disadvantage: Control is complex. }\end{array}$ \\
\hline Figure $11[38]$ & $515 \mathrm{~W}$ & $\begin{array}{l}2 \text { Capacitor } \\
(100 \mu \mathrm{F}, 100 \mu \mathrm{F}) \\
+4 \text { Switches }\end{array}$ & $\begin{array}{l}\text { In parallel } \\
\text { (AC side) }\end{array}$ & $\begin{array}{l}\text { Efficiency: } 85.05 \% \text {. } \\
\text { Effect: The input voltage } \\
\text { ripple is reduced to } 3.9 \% \\
\text { of DC-link voltage. }\end{array}$ & $\begin{array}{l}\text { Advantage: Simple control. } \\
\text { Disadvantages: Extra switches for } \\
\text { decoupling circuits exist on both } \\
\text { AC-sides. }\end{array}$ \\
\hline Figure $12 b$ [39] & $1 \mathrm{~kW}$ & $\begin{array}{c}2 \text { Capacitors } \\
(32 \mu \mathrm{F}, 32 \mu \mathrm{F})+ \\
2 \text { Switches }\end{array}$ & $\begin{array}{l}\text { In parallel } \\
\text { (AC side) }\end{array}$ & $\begin{array}{l}\text { Effect: The input current } \\
\text { ripple is reduced to } 3 \% \text { of } \\
\text { DC-link current. }\end{array}$ & $\begin{array}{l}\text { Advantage: Bridge arm } \\
\text { multiplexing. } \\
\text { Disadvantage: Control is complex. }\end{array}$ \\
\hline Figure 13 [40] & $1 \mathrm{~kW}$ & $\begin{array}{l}1 \text { Capacitor } \\
(50 \mu \mathrm{F})+2 \\
\text { Switches }\end{array}$ & / & $\begin{array}{l}\text { Effect: The input current } \\
\text { ripple is reduced to } 4.275 \% \\
\text { of DC-link current. The } \\
\text { input voltage ripple can be } \\
\text { reduced to } 8.6 \% \text { of DC-link } \\
\text { voltage. }\end{array}$ & $\begin{array}{l}\text { Advantage: Switch multiplexing. } \\
\text { Disadvantages: Endangering } \\
\text { system stability due to a bridge arm } \\
\text { with three switches. }\end{array}$ \\
\hline Figure $14 \mathrm{a}[41]$ & $217.5 \mathrm{~W}$ & $\begin{array}{l}1 \text { Capacitor } \\
(90 \mu \mathrm{F})\end{array}$ & / & $\begin{array}{l}\text { THD: } 4.63 \% \text {. } \\
\text { Efficiency: The power } \\
\text { losses caused by } \\
\text { decoupling circuit is about } \\
1.5 \% \\
\text { Dynamic response: } \\
\text { within } 1 \mathrm{~ms} \text {. }\end{array}$ & $\begin{array}{l}\text { Advantage: No extra switches. } \\
\text { Disadvantage: Control is complex. }\end{array}$ \\
\hline Figure $14 \mathrm{~b}$ [42] & $217.5 \mathrm{~W}$ & $\begin{array}{l}2 \text { Capacitors } \\
(90 \mu \mathrm{F} \text { total })\end{array}$ & / & $\begin{array}{l}\text { THD: } 4.47 \% \text {. } \\
\text { Effect: Second-order } \\
\text { harmonic current ripple is } \\
\text { reduced to } 2.36 \% \\
\text { Dynamic response: } \\
\text { within } 1 \mathrm{~ms} \text {. }\end{array}$ & $\begin{array}{l}\text { Advantages: No extra switches, } \\
\text { More optional circuit states. } \\
\text { Disadvantage: complex control }\end{array}$ \\
\hline
\end{tabular}

Author Contributions: This paper was a collaborative effort among all authors.

Funding: This work is supported by the National Natural Science Foundation of China (51777181), the Lite-On Research Funding, the State Key Laboratory of Reliability and Intelligence of Electrical Equipment (No. EERIKF2018002), Hebei University of Technology, Postdoctoral Research Program of Hebei Province (B2018003010), and Hundred Excellent Innovation Talents Support Program of Hebei Province (SLRC2017059).

Conflicts of Interest: The authors declare no conflicts of interest.

\section{Abbreviations}

Acronyms

$\begin{array}{ll}\text { AD } & \text { active damping } \\ \text { UPS } & \text { uninterruptible power supply } \\ \text { SMES } & \text { superconductor magnetic energy storage } \\ \text { HVDC } & \text { high voltage direct current } \\ \text { FACT } & \text { flexible AC transmission } \\ \text { MPPT } & \text { maximum power point tracking } \\ \text { LED } & \text { light emitting diode } \\ \text { Nomenclature } & \\ u_{a c} & \text { grid voltage } \\ i_{a c} & \text { grid current } \\ \varphi & \text { phase-angle between grid voltage and current } \\ P_{a c} & \text { output power } \\ P_{o} & \text { constant power } \\ P_{r} & \text { ripple power }\end{array}$




\section{References}

1. Senthilnathan, K.; Annapoorani, I. Multi-Port Current Source Inverter for Smart Microgrid Applications: A Cyber Physical Paradigm. Electronics 2019, 8, 1. [CrossRef]

2. Colombi, S.; Balblano, C. Clean Input UPS with Fast Rectifier Control and Improved Battery Life. U.S. Patent US7768805, 3 August 2010.

3. Wang, Z.; Jiang, L.; Zou, Z.; Cheng, M. Operation of SMES for the current source inverter fed distributed power system under islanding mode. IEEE Trans. Appl. Superconduct. 2012, 23, 5700404. [CrossRef]

4. Guo, X. A novel CH5 inverter for single-phase transformerless photovoltaic system applications. IEEE Trans. Circ. Syst. II Express Briefs 2017, 64, 1197-1201. [CrossRef]

5. Liang, J.; Nami, A.; Dijkhuizen, F.; Tenca, P.; Sastry, J. Current source modular multilevel converter for HVDC and FACTS. In Proceedings of the European Conference on Power Electronics and Applications, Lille, France, 2-6 September 2013; pp. 1-10.

6. Kerekes, T.; Teodorescu, R.; Liserre, M.; Klumpner, C.; Sumner, M. Evaluation of Three-Phase Transformerless Photovoltaic Inverter Topologies. IEEE Trans. Power Electron. 2009, 24, 2202-2211. [CrossRef]

7. Graditi, G.; Adinolfi, G.; Femia, N.; Vitelli, M. Comparative analysis of Synchronous Rectification Boost and Diode Rectification Boost converter for DMPPT applications. In Proceedings of the 2011 IEEE International Symposium on Industrial Electronics, Gdansk, Poland, 27-30 June 2011; pp. 1000-1005.

8. Yang, B.; Li, W.; Gu, Y.; Cui, W.; He, X. Improved Transformerless Inverter with Common-Mode Leakage Current Elimination for a Photovoltaic Grid-Connected Power System. IEEE Trans. Power Electron. 2012, 27, 752-762. [CrossRef]

9. Cecati, C.; Khalid, H.A.; Tinari, M.; Adinolfi, G.; Graditi, G. DC NanoGrid with Renewable Energy Sources and Modular DC/DC LLC Converter Building Block. IET Power Electron. 2016, 10, 536-544. [CrossRef]

10. Adinolfi, G.; Graditi, G.; Siano, P.; Piccolo, A. Multi-Objective Optimal Design of Photovoltaic Synchronous Boost Converters Assessing Efficiency, Reliability and Cost Savings. IEEE Trans. Ind. Inform. 2015, 11, 1038-1048. [CrossRef]

11. Cavalcanti, M.C.; De Oliveira, K.C.; De Farias, A.M.; Neves, F.A.; Azevedo, G.M.; Camboim, F.C. Modulation Techniques to Eliminate Leakage Currents in Transformerless Three-Phase Photovoltaic Systems. IEEE Trans. Ind. Electron. 2010, 57, 1360-1368. [CrossRef]

12. Chen, W.; Hui, S.R. Elimination of an electrolytic capacitor in AC/DC light-emitting diode (LED) driver with high input power factor and constant output current. IEEE Trans. Power Electron. 2011, 27, 1598-1607. [CrossRef]

13. Kim, H.; Shin, K.G. DESA: Dependable, Efficient, Scalable Architecture for management of large-scale batteries. IEEE Trans. Ind. Inform. 2011, 8, 406-417. [CrossRef]

14. Shimizu, T.; Fujita, T.; Kimura, G.; Hirose, J. A unity power factor PWM rectifier with DC ripple compensation. IEEE Trans. Ind. Electron. 1997, 44, 447-455. [CrossRef]

15. Hu, H.; Harb, S.; Kutkut, N.; Batarseh, I.; Shen, Z.J. A review of power decoupling techniques for microinverters with three different decoupling capacitor locations in PV systems. IEEE Trans. Power Electron. 2012, 28, 2711-2726. [CrossRef]

16. Guo, X.; Zhang, X.; Guan, H.; Kerekes, T.; Blaabjerg, F. Three phase ZVR topology and modulation strategy for transformerless PV system. IEEE Trans. Power Electron. 2019, 34, 1017-1021. [CrossRef]

17. Schimpf, F.; Norum, L. Effective use of film capacitors in single-phase PV-inverters by active power decoupling. In Proceedings of the 36th Annual Conference on IEEE Industrial Electronics Society, Glendale, AZ, USA, 7-10 November 2010; pp. 2784-2789.

18. Yang, Y.; Ruan, X.; Zhang, L.; He, J.; Ye, Z. Feed-forward scheme for an electrolytic capacitor-less AC/DC LED driver to reduce output current ripple. IEEE Trans. Power Electron. 2014, 29, 5508-5517. [CrossRef]

19. Cao, X.; Zhong, Q.; Ming, W. Ripple eliminator to smooth DC-Bus voltage and reduce the total capacitance required. IEEE Trans. Power Electron. 2015, 62, 2224-2235. [CrossRef]

20. Krein, P.T.; Balog, R.S.; Mirjafari, M. Minimum energy and capacitance requirements for single-phase inverters and rectifiers using a ripple port. IEEE Trans. Power Electron. 2012, 27, 4690-4698. [CrossRef]

21. Harb, S.; Mirjafari, M.; Balog, R.S. Ripple-port module-integrated inverter for grid-connected PV applications. IEEE Trans. Ind. Appl. 2013, 49, 2692-2698. [CrossRef] 
22. Nussbaumer, T.; Kolar, J.W. Improving mains current quality for three-phase three-switch buck-type PWM rectifiers. IEEE Trans. Power Electron. 2006, 21, 967-973. [CrossRef]

23. Guo, X.; Yang, Y.; Zhu, T. ESI: A novel three-phase inverter with leakage current attenuation for transformerless PV systems. IEEE Trans. Ind. Electron. 2018, 65, 2967-2974. [CrossRef]

24. Nussbaumer, T.; Baumann, M.; Kolar, J.W. Comprehensive design of a three-phase three-switch buck-type PWM rectifier. IEEE Trans. Power Electron. 2007, 22, 551-562. [CrossRef]

25. Tang, Y.; Blaabjerg, F.; Loh, P.C.; Jin, C.; Wang, P. Decoupling of fluctuating power in single-phase systems through a symmetrical half-bridge circuit. IEEE Trans. Power Electron. 2015, 30, 1855-1865. [CrossRef]

26. Serban, I. A novel transistor-less power decoupling solution for single-phase inverters. In Proceedings of the 39th Annual Conference of the IEEE Industrial Electronics Society, Vienna, Austria, 10-13 November 2013; pp. 1496-1500.

27. Tang, Y.; Yao, W.; Wang, H.; Loh, P.C.; Blaabjerg, F. Transformerless photovoltaic inverters with leakage current and pulsating power elimination. In Proceedings of the 9th International Conference on Power Electronics and ECCE Asia, Seoul, Korea, 1-5 June 2015; pp. 115-122.

28. Hu, H.; Harb, S.; Kutkut, N.; Batarseh, I.; Shen, Z.J. Power decoupling techniques for micro-inverters in PV systems-a review. In Proceedings of the 2010 IEEE Energy Conversion Congress and Exposition, Atlanta, GA, USA, 12-16 September 2010; pp. 3235-3240.

29. Takahashi, H.; Takaoka, N.; Gutierrez, R.R.R.; Itoh, J.-I. Power decoupling method for isolated dc to single-phase ac converter using matrix converter. In Proceedings of the 20th European Conference on Power Electronics and Applications, Riga, Latvia, 17-21 September 2018; pp. 1-10.

30. Cai, W.; Liu, B.; Duan, S.; Jiang, L. Power flow control and optimization of a three-port converter for photovoltaic-storage hybrid system. In Proceedings of the IEEE Energy Conversion Congress and Exposition, Raleigh, NC, USA, 15-20 September 2012; pp. 4121-4128.

31. Han, H.; Liu, Y.; Sun, Y.; Su, M.; Xiong, W. Single-phase current source converter with power decoupling capability using a series-connected active buffer. IET Power Electron. 2015, 8, 700-707. [CrossRef]

32. Liu, Y.; Sun, Y.; Su, M.; Li, X.; Ning, S. A Single Phase AC/DC/AC Converter with Unified Ripple Power Decoupling. IET Power Electron. 2018, 33, 3204-3217. [CrossRef]

33. Ohnuma, Y.; Orikawa, K.; Itoh, J.I. A single-phase current source PV inverter with power decoupling capability using an active buffer. IEEE Trans. Ind. Appl. 2014, 51, 531-538. [CrossRef]

34. Román, L.T.; Silva, L.S. A single-phase current-source inverter with active power filters for grid-tied PV systems. In Proceedings of the 3rd IEEE International Symposium on Power Electronics for Distributed Generation Systems, Aalborg, Denmark, 25-28 June 2012; pp. 349-356.

35. Wei, L.; Skibinski, G.L.; Lukaszewski, R.A. Auxiliary Circuit for Use with Three-Phase Drive with Current Source Inverter Powering a Single-Phase Load. U.S. Patent 7518891B2, 14 April 2009.

36. Vitorino, M.A.; Correa, M.B.D.R. Compensation of DC link oscillation in single-phase VSI and CSI converters for photovoltaic grid connection. IEEE Trans. Ind. Appl. 2014, 50, 2021-2028. [CrossRef]

37. Su, M.; Pan, P.; Long, X.; Sun, Y.; Yang, J. An active power-decoupling method for single-phase AC-DC converters. IEEE Trans. Ind. Inf. 2014, 10, 461-468. [CrossRef]

38. Vitorino, M.A.; Wang, R.; de Rossiter Corrêa, M.B.; Boroyevich, D. Compensation of DC-Link Oscillation in Single-Phase-to-Single-Phase VSC/CSC and Power Density Comparison. IET Power Electron. 2014, 50, 2021-2028. [CrossRef]

39. Vitorino, M.A.; Correa, M.B.R.; Jacobina, C.B. Single-phase power compensation in a current source converter. In Proceedings of the 2013 IEEE Energy Conversion Congress and Exposition, Denver, CO, USA, 15-19 September 2013; pp. 5288-5293.

40. Vitorino, M.A.; Hartmann, L.V.; Fernandes, D.A.; Silva, L.E.; Correa, M.B.R. Single-phase current source converter with new modulation approach and power decoupling. IEEE Appl. Power Electron. Conf. Expo. 2014, 16, 2200-2207.

41. Liu, Y.; Sun, Y.; Su, M. Active power compensation method for single-phase current source rectifier without extra active switches. IET Power Electron. 2016, 9, 1719-1726. [CrossRef]

42. Sun, Y.; Liu, Y.; Su, M. Active power decoupling method for single-phase current-source rectifer with no additional active switches. IEEE Trans. Power Electron. 2016, 31, 5644-5653. [CrossRef]

43. Itoh, J.I.; Fayashi, F. Ripple current reduction of a fuel cell for a single-phase isolated converter using a dc active filter with a center tap. IEEE Trans. Power Electron. 2010, 25, 550-556. [CrossRef] 
44. Larsson, T.; Ostlund, S. Active DC link filter for two frequency electric locomotives. In Proceedings of the International Conference on Electric Railways in a United Europe, Amsterdam, The Netherlands, 27-30 March 1995; pp. 97-100.

45. Cai, W.; Jiang, L.; Liu, B.; Zou, C. A power decoupling method based on four-switch three-port DC/DC/AC converter in dc microgrid. IEEE Trans. Ind. Appl. 2015, 51, 336-343. [CrossRef]

46. Shimizu, T.; Fujioka, Y.; Kimura, G. DC ripples current reduction method on a single phase PWM voltage source converter. In Proceedings of the IEEE Power Conversion Conference, Nagaoka, Japan, 6 August 1998; Volume 1, pp. 525-530.

47. Shimizu, T.; Jin, Y.; Kimura, G. DC ripple current reduction on a single-phase PWM voltage-source rectifier. IEEE Trans. Ind. Appl. 2000, 36, 1419-1429. [CrossRef]

48. Guo, X.; Yang, Y.; Wang, X. Optimal space vector modulation of current source converter for dc-link current ripple reduction. IEEE Trans. Ind. Electron. 2019, 66, 1671-1680. [CrossRef]

49. Tsuno, K.; Shimizu, T.; Wada, K.; Ishii, K. Optimization of the DC ripples energy compensating circuit on a single-phase voltage source PWM rectifier. In Proceedings of the IEEE 35th Annual Power Electronics Specialists Conference (IEEE Cat. No.04CH37551), Aachen, Germany, 20-25 June 2004; pp. 316-321.

(C) 2019 by the authors. Licensee MDPI, Basel, Switzerland. This article is an open access article distributed under the terms and conditions of the Creative Commons Attribution (CC BY) license (http:/ / creativecommons.org/licenses/by/4.0/). 